\title{
Imperatives of Political Leadership with Reference to George Orwell's Animal Farm
}

\author{
Ndubuisi H. Onyemelukwe ${ }^{1}$, Catherine O. Ogbechie ${ }^{1} \&$ Jemimah O. Ekechi ${ }^{1}$ \\ ${ }^{1}$ Department of Languages, Yaba College of Technology, Yaba-Lagos, Nigeria \\ Correspondence: Ndubuisi H. Onyemelukwe, Department of Languages, Yaba College of Technology, \\ Yaba-Lagos, Nigeria. E-mail: hyginusndubuisi@yahoo.com
}

\author{
Received: September 18, 2014 Accepted: October 28, 2014 Online Published: November 25, 2014 \\ doi:10.5539/ijel.v4n6p87 URL: http://dx.doi.org/10.5539/ijel.v4n6p87
}

\begin{abstract}
Several great minds cum social critics such as Orwell $(1944,1948)$, Achebe $(1984,2012)$, Odumegwu-Ojukwu (1989), Maxwell (2014), Ohiwerei (2008), Isola (2008), Onyemelukwe and Oriaku (2011) as well as Onyemelukwe $(2006,2011)$ have highlighted the crucial role of political leadership in nation-building, identifying leadership failure to be the bane of failed nations like Nigeria, Afghanistan, Somalia and Iraq. Against this backdrop, this study undertakes to deduce and expound some cardinal political leadership imperatives, the objective being to prompt failed nations to appropriate the imperatives and bounce back as viable polities with enormous potentials for becoming developed nations. The study anchors on the theoretical premise that political leadership must be altruistic and strategic to be effective. The imperatives of political leadership expounded in the study are deduced from the quasi-political activities of Animal Farm as an unnatural but naturalised polity under Napoleon's dictatorship. George Orwell's Animal Farm is purposively selected for the study on account of its unbeatable sweet satirical exposition on totalitarianism as an abominable political leadership style which concurrently, but implicitly provides indispensable ideals applicable to political leadership. Foremost among the cardinal imperatives evolved in the study is that democracy is the only acceptable political leadership ideology. This notion is established in the study relying on Orwell's implicit but exclusive advocacy for it in Animal Farm as in Nineteen Eighty-four which is strongly underpinned by Achebe (1958, 1966, 1987) and Onyemelukwe's (2006, 2011) same position. The trio of Orwell, Achebe and Onyemelukwe grant exclusive ratification to democracy which must be participatory and unbridled, because they see nothing good about totalitarianism and other right-wing political leadership ideologies such as fascism, maxism, stalinism and constitutional monarchy. In pragmatic terms, this foremost imperative translates to exemplary leadership which courageously serves to constantly reassure the led that they are neither enslaved to the leaders nor misled by them. To sustain effective political leadership, the led in every nation are enjoined in the study to ensure appreciative enlightened followership. Enlightened followership is such that monitors leadership by regularly demanding account of stewardship from the leaders. To live up to this ideal the led, as much as the leaders in a polity, must prioritise high-quality formal education to avoid hero-worshipping their leaders, so that they do not become disguised despots.
\end{abstract}

Keywords: totalitarianism, political leadership, ideology, imperatives, animalism, stalinism

\section{Introduction}

Animal Farm, according to Brander (1960:89), is George Orwell's (Orwell, henceforth) best work, while Nineteen Eighty-four is his most popular one. Brander reasons that Animal Farm is Orwell's best work, because it projects his ability for imaginative creation rather than for description and recollection demonstrated in his other works. The secret behind Brander's superlative ranking of Animal Farm resides in the allegorical nature of the fairy-like narrative unfolded in the novelette.

The novelette's allegorical tenor anchors its superlative rating on account of the lofty ideational constructs symbolised by the flat characters which unfold its plot, especially the animal characters. The animal characters are of more interest in view of the fascinating philosophical manner by which their animalism connects very pertinent issues about life in general but political leadership in particular. The issues raised about political leadership in the novelette are such that are perpetually relevant, irrespective of their timing. In other words, not minding that the issues are getting close to being a century old, they are still very much germane, especially in 
developing countries across the globe. Political leadership issues raised in Animal Farm are time-honoured indeed, since it was published in 1944.

The issues are particularly of global interest in relation to developing countries, because many such countries in Africa and beyond such as Nigeria, Tunisia, Egypt, Somalia, Iran, Iraq and Syria have perennially been diagnosed to be suffering from leadership failure. In some of these countries like Nigeria, Afghanistan, Somalia and Iraq the failure of leadership is of such magnitude that they are considered to be failed nations, given their too low a rating in terms of national development parameters. See Akpenyi and Onyemelukwe (2012), Achebe (2012), Iwara (2008), Isola (2008) and Ohiwerei (2008) for the parameters.

It is surely not in doubt that failed nations are incidental to failed leadership. Hence, Achebe (2012: 250) notes that:

A failed state (nation) is one that is unable to perform its duties on several levels: when violence cascades into an all-out internal war, when standard of living massively deteriorate, when the infrastructure of ordinary life decays and when the greed of rulers overwhelms their responsibilities to better their people and their surroundings.

Indisputably, all the indices of a failed nation contained in Achebe's assertion apply to the countries identified as failed nations above, hence, their listing in 2011 failed states index. See http.//www.foreighnpolicy.com/failedstates (July/August). In Nigeria, particularly, current insecurity alarms demonstrate, most aptly, that 'violence has cascaded into an all-out internal war,' no thanks to Boko Haram's senselessness which has consumed well over 5000 Nigerians with more than 20,000 rendered homeless according to the human rights groups in the country as noted by Adekambi (2014:25).

In the light of the overwhelming threat to nation-building faced by failed nations, it is salient to recall and highlight some imperatives of political leadership so that failed nations, reconnecting them, can revive their leadership and bounce back to the desirable status of viable nations.

Consequently, this study targets the explication of such political leadership imperatives as may be deduced from the fictional world of Animal Farm, selected purposively for the study. Animal Farm is selected for the study on account of its unbeatable sweet satirical exposition on totalitarianism as an abominable political leadership style which concurrently, but implicitly provides indispensable ideals applicable to political leadership. In view of the obvious truth that political leadership can scarcely be discussed without reference to appreciative enlightened followership, the study also aims to expound some attitudinal ideals universally expected of the led in a political entity, still within the intra-textual situational context of Animal Farm. Before cracking the objectified explications, the theoretical premise for the study is first captured in the next section.

\section{Theoretical Premise: Altruistic Strategic Political Leadership}

An interesting definition of a leader by Maxwell (2014) states that a leader is one who knows the way, shows the way and goes the way. This definition can be segmented into two aspects: the cognitive and the pragmatic. The cognitive aspect of it comprises '... who knows the way' and '...who shows the way,' while the pragmatic aspect comprises '...who goes the way.' So segmented, it becomes apparent that Maxwell credits intellectuality cum responsibility to a leader. Intellectuality refers to being knowledgeable; while responsibility means being ever ready to demonstrate exemplary leadership. Simply stated, the three segments of the definition in focus jointly assert that a leader should not only be an executive legislator, but also a champion of his/her legislations. In other words, it is imperatively expected of a political leader to always be the first to do that which he/she says ought to be done. In legal parlance, a leader must at all times and in all situations be subject to the rule of law. Hence, his utterances and actions must always be strictly guided by the statutes, policies, principles, maxims, rules, regulations and bye-laws put in place or co-opted by his/her leadership. In a popular metaphorical term, a political leader must never be a sacred cow and must never harbour a sacred cow. For avoidance of doubt, it is hereby observed that the cognitive personality of a political leader as already expounded takes for granted the notion that such a leader should and must be a man or woman with clear-cut visions (foresights) and missions (specific goals).

The foregoing analytical reflection on the definition of a political leader certainly provides a useful insight about what is political leadership, namely, ideational and pragmatic acts of deciding, directing and championing beneficial lines of action for the led. This definition indicates that the baseline of leadership is the impulsion and expulsion of uncommon creative positive ideas just as it incubates painstaking sacrificial service to the led. Consequently, Odumegwu-Ojukwu (1989: 180) asserts that: 
Service to a people is not a profession. It is a vocation and a leader must make a lot of sacrifices for it. A leader does not complain when things are not going too well since that is one of the occupational hazards. A leader must not try to cushion himself against the future by amassing wealth. Though the temptation is great, there is nothing more counter-productive in leadership than corruption. A leader, apart from constantly reassuring his people, must always make himself acceptable to everyone. To do this, he has to be above board in all his dealings.

One clear deduction from Odumegwu-Ojukwu's cogitation above is that leadership must be self-less. Self-less leadership translates to altruistic leadership and is the fundamental theoretical thrust of this exposition. To ensure altruistic leadership, 'the burden of leadership' must be thrust upon self-less leaders. Hence, selflessness is the sole determinant of who should be a leader rather than age, social class, sex, socio-economic status, religious affiliation and/or educational qualification. Nothing in the last quashed factor ratifies 'visionlessness' (ignorance or zero sense of direction) as a political leadership personality trait. This assertion is pertinent in view of the self-evident truth that educational qualification does not necessarily equate intellectuality or cognitive ability which bestows visionary capacity to a leader as incorporated in the hypothetical definition above. Nevertheless, it is not denied in this study that formal education, if effective, enhances cognitive ability, and is therefore, an asset to a political leader.

Just like education, political leadership is expected to be effective. To be effective, such leadership must be strategic. Strategic political leadership is futuristic, anticipatory or proactive. For strategic political leadership to be in place, the leaders must foresee their leadership tasks well ahead of time and plan methodically for their result-oriented execution. This assertion means that strategic leadership in this regard entails strategic leadership planning with no loss of focus on immediate leadership imperatives. Note that strategic political leadership is sharply at variance with conventional political leadership which focuses solely on day-to-day leadership responsibilities. See Ewedemi (2011:9-54) for deeper insights into strategic leadership within an institutional context.

The following concise reference to Akpenyi and Onyemelukwe (2012:7) captures the working notion of political leadership in this study. The duo relies on Ohiwerei (2008) to conceptualise the essentials of this leadership type as reproduced below:

It is already pointed out that effective political leadership is a key determinant of national development. Effective leadership demands that servant-leaders be entrusted with positions of responsibility in the polity. Servant-leaders are those who see leadership as service and not as a means of corrupt self-enrichment. Such leaders must be result-oriented and continually be:

(a) committed to moral (legal) excellence

(b) committed to effective service delivery

(c) committed to national economic growth

(d) committed to giving: giving the society instead of doing otherwise.

(Maxwell's leadership postulations as cited by Ohiwerei (2008)).

If in accordance with Maxwell's postulation (a), the political leaders of a nation must possess sound moral scruples their education must embody impeccable moral instructions which should constantly be refreshed by effective annual retreats.

Observe that the foregoing Akpenyi and Onyemelukwe's notion of political leadership is in tandem with Odumegwu-Ojukwu's notion of national leadership which is also anchored on servant-leadership:

A true national leader must be a servant to all and not servant to some but lord to others. He must not only rise above sectional interest but must be seen to have done so. In the new dispensation, ethnicity will be counter-productive and certainly not viable as a ladder to political power.... (ibid: 181)

By and large, taking together, the authorities cited in this theoretical permutation in addition to countless unreferenced ones, it is glaringly clear that leadership, if authentic, is conceptually altruistic and strategic, hence the compassionate call herein on political leaders and potential ones across the globe to make it a reality.

\section{An Analytical Panorama on Political Leadership in the World of Animal Farm}

The purpose of this section is to contextualise and discuss the imperatives of political leadership cum followership in Orwell's Animal Farm. The section concurrently focuses on followership, because there can be no leadership without followership. The explication objectified in the section is anchored on the quasi-political 
activities unfolded in Manor Farm, the immediate geographical setting of the allegorical text slated for analysis here. The contextualised discussion here is done relying on the insights arising from political leadership as unfolded in Manor Farm as an unnatural but naturalised polity.

Manor Farm is an unnatural but naturalised polity, because the obvious reality is that no political entity is identified as a farm just as none is exclusively populated and manned by animals as seen in the farm the governance and government of which is wrested from Mr. Jones and his four lieutenants very early in the narrative. That is, the farm was originally governed by human beings with animals as their subjects, but the animals rose up spontaneously one day and dethroned its human government. Hence, as a mere story, Animal Farm is simply a fantasy, and as such, a ridiculously incredible narrative. Nevertheless, its story is narrated with so much relish that the reader suspends disbelief, most willingly. The reader naturally suspends disbelief, realising that the story is only a seeming fairy tale, being Orwell's allegorical construction against totalitarianism. Totalitarianism, as stated by Onyemelukwe (2006:31), contrasts sharply with democracy and constitutional monarchy. It is, therefore, synonymous with absolute monarchy, its sole object being absolute political control with zero tolerance for opposition, i.e., pure despotism or raw dictatorship. See Appadorai (1975). Hence, Orwell's Animal Farm exclusively advocates democracy, albeit, implicitly. Democracy is so ratified in the allegory, because as noted by Onyemelukwe (2011) it is representative and participatory, and so, people-oriented.

Manor Farm under human and animal government is a mirror reflection of totalitarianism. Under Jones and his lieutenants the farm is doubtlessly a mockery of the average totalitarian state. Orwell portrays it as such to dramatically intimate the reader that the final end of a totalitarian government is dethronement. In other words, to Orwell as to Onyemelukwe $(2011: 69,191)$ totalitarianism is absolutely intolerable, and so, unacceptable as a political leadership ideology. The farm witnesses a worse totalitarian form of government under the raw despotic leadership of Napoleon right from the moment it becomes an all-animal polity, subject to the principles of animalism, following which it is renamed Animal Farm. Napoleon's raw dictatorial administration as a replacement for Jones' serves to aptly caution against revolution and revolutionists in a totalitarian or pseudo-democratic state. By that construction, Orwell sharply alerts the citizenry of such a state to beware of emergent revolutionists, because they are never better than the government in power. They are at best as absolute as the government in power. That is, revolution is no solution for oppressive political leadership, but radical psychic transformation and ideological re-engineering. The foregoing Orwellian notion about revolution and revolutionists finds inter-textual reciprocation in Nineteen Eighty-four, another Orwellian fiction. See Onyemelukwe (ibid: 210-211).

In view of the insights provided in the last paragraph before this, Animal farm can rightly be deconstructed as a satire of totalitarian rule, certainly, of the Russian type under Stalin. Brander (1960:96) identifies it as the most brilliant satire of modern times. Disguised as a charming appropriate fairy story for children, it deserves Brander's rating, obviously because it is written in good humour quite unlike his other works, especially Nineteen Eighty-four (1948). In other words, Animal farm as an Orwellian fiction unravels a juvenile satire. As already stated, it is a high-quality satire, a million thanks to Bernard Shaw and H.G. Wells and Gay's animal narratives from which Orwell drew much inspiration for its writing. Satire as a literary device, according to Onyemelukwe (ibid: 209), entails criticising and lampooning. In its juvenile form, it is considered beautiful, howbeit, without nullifying its criticising and lampooning objectives.

Why has Orwell chosen to beautifully satirise totalitarianism in Animal farm? Broadly captured, Orwell's satirical project in the novelette is targeted against totalitarianism, because as already asserted, it is completely and totally unacceptable as a political leadership approach. This assertion means that nothing is good about totalitarianism. Nothing is good about totalitarianism in the light of its specific innate attributes as clearly identified by Onyemelukwe (2006:37-44). As analytically shown in subsequent paragraphs, all the innate attributes of totalitarianism identified by Onyemelukwe (ibid.) reflect, glaringly, in Animal Farm under Napoleon's dictatorship.

Totalitarianism naturally attracts opposition, because it emasculates individuality. This attribute of the concept explains the rebellion against Napoleon by other animals towards the end of the story as for that against Jones as the lord of the manor at the onset. The rebellion against Jones is more illustrative in this regard. Envisioned and prophesied by Old Major, it depicts what it means to emasculate individuality. This observation reflects in Old Major's most striking opening remarks in his classical visionary speech which subsequently triggered the rebellion much sooner than anticipated: 
Now, comrades, what is the nature of this life of ours? Let us face it: our lives are miserable, laborious and short. We are born; we are given just so much food as will keep the breadth in our bodies, and those of us who are capable of it are forced to work to the last atom of our strength and the very instant that our usefulness has come to an end we are slaughtered with hideous cruelty. No animal in England knows the meaning of happiness or leisure after he is a year old. No animal in England is free. The life of an animal is misery and slavery. That is the plain truth. (p.3)

Indisputably, Major's opening remarks above captures the basis of his proposed collective opposition to Jones' despotic administration, namely, denial of personal freedom which embeds countless other oppressive indices such as being wantonly denied the right to life and criminal exploitation.

The very nature of totalitarianism compels officials of the government in power to assume split personality. Split personality connotes false life, i.e., insincerity, deception or arrogance all of which translate to policy inconsistence in governance or self-preserving ideological dilution in political leadership terms. Napoleon's dictatorship reflects false life at its peak which he uses Squealer to seemingly mask. Hence, despite the prohibition against dealing with human beings as also against using items strictly associated with them in line with the principles of animalism, Napoleon contracts Mr. Whymper, a solicitor, to serve as an intermediary between Animal Farm and the external world. This contract incubates trading as subsequently evident in the text which also contravenes the principles of animalism. Moreover, Napoleon and few other pigs begin to use ribbons after sometime just as they lay in Jones' bed, howbeit, without the bed sheets. Again, they enjoy much bigger rations of meal than all other animals in the farm, contrary to the maxim of equality encoded in the principles of animalism, namely, that all animals are equal. Consequently, this maxim like all others is secretly re-coded to justify the unjust self-granted privileges. So, it now reads, 'all animals are equal, but some are more equal than others.' What can we say about Napoleon's sale of most hard-working Boxer to a horse butcher under the guise of providing him with 'medicare'?

The height of Napoleon's split personality which embodies another inherent attribute of a totalitarian regime is summary execution of both his real and perceived enemies, thus, violating the principle of animalism that proscribes the killing of an animal by another animal as signified in their popular refrain: Four legs bad, two legs good. The foregoing violation demonstrates that totalitarianism is absolutely intolerant of opposition, even as it naturally triggers it just as it renders the notion of equality a mirage. Totalitarianism repels opposition to ensure self-preservation for the despot in control. Self-preservation is the first cardinal preoccupation of a despot, because to him, power possession is an end rather than a means. Hence, every potential despot seeks power for the sake of it, i.e., just for the glamour that goes with it. In the same vein every despot holds power strictly for the glamour of it. In other words, self-indulgence is the despot's perpetual motivating force, hence, its zero tolerance for opposition. It is, therefore, no wonder that in a single day within the twinkle of an eye Napoleon executed four pigs, three hens, a goose, four sheep and several other animals for various offences such as enemy collaboration, non-compliance and murder.

Given the attribute of despotism expounded in the paragraph immediately before this, it follows that the only friends of a despot are sycophants and blind loyalists. This observation explains the friendship between Napoleon, the dogs, the pigs and his other blind loyalists and squealer, his sycophant-in-chief cum sole tactful propagandist. This assertion indicates that totalitarianism thrives on sycophancy and deceptive propaganda. Consequently, Napoleon is always right, courtesy of Squealer and Boxer. Consequently also, the release of spurious socio-economic indices to create the impression of favourable Animal Farm economy becomes imperative, even as some of the animals subtly question the indices.

Another inherent attribute of despotism is intimidation anchored on coercive force which hinges on draconian decrees and hooliganism. Hooliganism gives expression to coercion and serves to give authoritarian force to the despot's decrees. This notion of totalitarianism explains the escort provided to Napoleon by nine dogs which in turn empowers him to issue decrees at random in total disregard of the principles of animalism. Consequently, to consolidate his leadership of Animal Farm which he usurped from Snowball as from the generality of the animals who preferred Snowball to him, he quickly outlaws debates at general assemblies, and thus, enthroned his totalitarian regime.

The manner by which Snowball is exiled from the farm by Napoleon provides another insight into the innate attribute of totalitarianism, namely, that it also thrives on militancy and victimization. In other words, Snowball suffers militant victimisation in the hand of Napoleon who incites the dogs against him in consequence of which he disappears into a hole to escape the murderous jaws of the dogs. It is imperative to note here that Snowball's only 'offence' against his assailant is opposing his tyranny in favour of democracy. In line with the principle of 
zero tolerance for opposition characteristic of despots, Napoleon eliminates him, most compulsively, to pave way for himself as the new lord of the manor.

Let it be noted at this juncture that Snowball's expulsion from the farm by Napoleon is a demonstration of the latter's capacity to suppress stiff internal opposition. Similarly, his ability to trace the collapse of the windmill to Snowball's activities in collaboration with his loyalists in the farm and to eventually complete the key infrastructure demonstrates his capacity to triumphantly deal with external enemy infiltration. Apparently, the foregoing competencies of Napoleon underscore the governance strengths attributable to despots. Nevertheless, it is doubtful if these strengths compensate for the heartless intrigues and brainwashing to which despots subject the citizenry just to have their way. How about their cruel exploitation of hardworking citizens signified by the eventual fate of Boxer?

Obligatory 'optionality' is another innate attribute of totalitarianism. It translates to brutal use of force which could be raw or soft. The raw form of it manifests as summary execution of real or perceived enemies as already contextualised in this study. Its soft form manifests as wicked official deception by which the despot pretentiously grants freedom of choice to the led, whereas in reality he compels them to succumb to his heartless commands. In demonstration of soft brutal use of force, Napoleon decrees Sunday afternoon work in his animal kingdom. The decree makes it optional, but stipulates that the ration of absent animals will be cut by fifty percent for the day (p. 37). In other words, Sunday afternoon work is compulsory, since no animal is ready to be starved.

Intrigue is another integral identity mark of totalitarianism as already signalled. Consequently, Napoleon, on the third Sunday following Snowball's expulsion, to the chagrin of the led in Animal Farm, announces his plan to build the windmill which he was strongly opposed to hitherto, obviously because it was Snowball's endearing initiative (p. 36). Doubtlessly, Napoleon co-opted this initiative of Snowball for credibility purposes, having seen how popular it is among his kingdom members on account of its super high utilitarian values. Constantly instilling fear in the led is part of Napoleon's intrigues. Hence, every now and then Squealer silences the animals over an unwelcome development by indirectly threatening them with a possible return of Mr. Jones, hence, his popular refrain: Surely you don't want Jones back.

Followership as seen in Animal Farm is far from being ideal. What accounts for paucity of followership in the pseudo-polity? At the immediate root of it is hero-worship. Hero-worship obtains between Napoleon and Squealer as between him and Boxer. It also obtains between Squealer and a host of other animals. From all indications in the farm, it is crystal clear that hero-worship gives impetus to despotism. Hence, Napoleon's dictatorship finds solid support in the hero-worship he received directly from Squealer and indirectly through Squealer from most other animals. Other factors that remotely rob off on followership in Animal Farm are stark illiteracy, ignorance and zero spirituality. Illiteracy and ignorance account for the chronic credulity too glaring in the farm among the led. Chronic credulity in the farm is epitomized in Boxer's maxim: Napoleon is always right, derived from his hero-worship mentality to the effect that if Comrade Napoleon says it, it must be right (p. 35).

Stark illiteracy is particularly personified in Clover with insignificant respite from Muriel's semi-literacy. From every indication, it is clear that massive ignorance of the led in the farm as expressed in their chronic credulity which is tied to their stark illiteracy and semi-literacy as a result of which they never bothered about the documentation of the principles of animalism which make up the constitution of the farm. Consequently, the few educated elites in Napoleon's cabinet represented by Squealer manipulated the constitution totally against the collective interest of the farm and thus paved way for the triumph of despotism in the farm.

Zero spirituality among the led in Animal Farm stems from Napoleon and consolidated by Squealer, obviously to dismantle every bit of impediment likely to forestall his selfish political agenda. It is, therefore, a consequence of brainwashing characteristic of a dictatorship as already pointed out. Hence, the led in the farm are staunchly dissuaded from nursing religious belief as signified in the dismissing of Moses' notion of Sugarcandy Mountain by the officials of the government in power. Sugarcandy refers to a celestial place of eternal happiness, an indispensable belief indicative of life after death held by every positive religious sect such as the Judeo-christian ones. The foregoing about zero spirituality evinces that such religions and their precepts are senseless to dictators as indisputably evident in real polities, even if the dictators in charge participate in devotional ceremonies as observed among military juntas in Africa and beyond.

\section{Conceptual Permutations on Political Leadership Arising from Napoleon's}

\subsection{Dictatorship in the World of Animal Farm}

The objective of this section is two-dimensional: to evolve some general cardinal political leadership imperatives as well as those of appreciative followership, since leadership and followership are two sides of a sheet as 
asserted in the introductory section above. This bipolar objective will be realised relying on logical deductions from Napoleon's totalitarian rule in Animal Farm.

The theoretical platform for this study and its analysis section assert that totalitarianism is sharply contrastive to constitutional, representative or participatory democracy (democracy, henceforth). In Animal Farm, while totalitarianism proves absolutely unacceptable in tandem with the theoretical construct which anchors the study, democracy is a generally welcome political leadership ideology. This explains why Snowball is the popularly preferred, albeit, uninstalled leader of Animal Farm (p.33), being a champion of democracy. The foremost pragmatic import of the foregoing reflection is that political leadership in general should and must take democratic approach. This pragmatic import mirrors Onyemelukwe's (2011) investigative finding on Achebe's Things Fall Apart (1958), A Man of the People (1966) and Anthills of the Savannah (1987) which establishes democracy as the only acceptable leadership ideology as far as it is unbridled. Democracy must not be bridled, else, it goes pseudo and pseudo-democracy is as unacceptable as totalitarianism, being synonymous with it.

Arising from Onyemelukwe's finding as from political leadership in Animal Farm is that political leadership should and must be positively ideological. Ensuring that political leadership is positively ideological practically means that leaders have populist sense of direction as dictated by their motivating visions. In other words, positive ideological political leadership is synonymous with populist purposeful political leadership which is imperative, because life is purpose-driven and political leadership is essentially about life, and so, about people. See Eagleton (1991) and Onyemelukwe (ibid.) for insightful exposition on various sheds of ideology. This positive ideological notion of political leadership reflects in the principles of animalism originated by Snowball, Napoleon and Squealer from Old Major's revolutionary leadership vision. Unfortunately, however, the ideology as fundamentally captured in Old Major's poetic anthem titled Beasts of England (pp. 7-8) was gradually watered down such that it became strictly self-serving, and consequently, lost its emancipating and egalitarian taste, no thanks to Napoleon's totalitarian impulse which found offensive tactful support in Squealer. One practical underlying message here is that political leaders must be knowledgeable, and so, are enjoined to be formally educated, since formal education enhances cognitive prowess which creates sensible vision.

Insights from the last paragraph before this show clearly that totalitarianism is in truth a negatively ideological political leadership style, being self-serving, hence, the pathological selfishness of every despot. It is negatively ideological, because to be positively ideological, it must seek the common good: the collective welfare of a great majority instead of just targeting a tiny group interest, positive ideologies being about large group interests. The foregoing cogitation in this paragraph explains the neglect of social contract by totalitarian governments all of which are strictly ruled by their whims and caprices. The multiple demerits of totalitarianism such as imposition, intolerance, subjugation and bullying account for its neglect of social contract. Observe that all the demerits translate to emasculation of individuality. Consequently, it is quite sharply opposed to democracy which permits individuality and promotes general positive attitudes to life. See Onyemelukwe (ibid: v).

As part of promoting general positive attitudes to life in the spirit of democracy, political leaders must never consider the nation they lead an island unto itself. Understanding that no nation is self-sufficient, the leaders of any particular nation should and must ensure beneficial international relations. The foregoing assertions in this paragraph are the logical deductions arising from Napoleon's secret dealings with Mr. Pilkington and Mr. Fredrick via Mr. Whimper. He interacted with them, having realised that Animal Farm could not survive by itself alone. Hence, nothing is wrong with this specific leadership initiative of Napoleon except the hypocrisy that surrounds it.

Ultimately, political leadership in whichever nation must be self-less as expounded in ection 2 above. Emphasis in this regard is regardless of the socio-economic ideology that governs it, else, the citizenry will suffer as is the case in Animal Farm which aptly demonstrates the oppressive maxim of Monki go de wok, Baboon go de shop or that of working like horses but eating like ants. Concomitant with altruistic political leadership as also expounded in Section 2 of the study is that leadership must be driven by the popular maxim which asserts that honesty is the best policy. The practical implication of this assertion is that political leaders must entrench and sustain policies that promote transparency and accountability unlike in Napoleon's dictatorship. This implication connects the spiritual dimension to leadership, namely, that leaders should and must regard themselves as servants of God, the super master of every mortal. Consequently, political leaders are expected to work painstakingly not only in service to the led, but also to God, the Super Master. The pragmatic import of this expectation is that political leadership must be sacrificial, seeking the interest of the led always, else, political leaders cannot rightly be regarded as servant-leaders. The spiritual dimension to political leadership is fundamentally imperative, because without it, leadership as such becomes an irredeemable selfish enterprise. 
Obviously, the absence of this spiritual dimension is the missing rib in Napoleon's government in consequence of which it becomes inevitably totalitarian.

Beyond selflessness, political leadership must thrive on leadership by example in line with Maxwell's definition of a leader, namely . . . he who shows the way. Exemplary political leadership is indispensable in view of the resolution in this study that it must be democratic. The essence of leadership by example is to ensure that the led feel no sense of enslavement, whatsoever, quite unlike what obtains with totalitarianism. This assertion explains why it is lacking in Napoleon's government in which leaders heap crushing heavy burdens on the heads and shoulders of the led without ever lifting a finger to show the way.

A further logical deduction from Jones' Manor Farm regime regarding political leadership is that political leaders should and must be impeccably disciplined. In this regard drunkenness is outlawed for all categories of political leaders, except they want to suffer the disgraceful fates of Jones: dethronement and extradition with battery. In accordance with the popular maxim that nobody makes headway in life without discipline as demonstrated by the unfortunate fates of Jones, we aver that political leaders embrace other aspects of self-discipline such as self-contentment, sexual discipline, dietary control and financial prudence. Heeding this counsel will help political leaders to guard against corrupt practices like illegal self-enrichment by means of embezzlement and other forms of financial misappropriation.

Let it now be stated that to sustain the imperatives of political leadership deduced and expounded in this section, followership must be aptly appreciative and enlightened. Fundamental to appreciative enlightened followership is compliance with legitimate statutes, rules, regulations and bye-laws. Sequel to compliance is respect for the leaders. In practical terms, the led must hold leaders in high esteem. Nothing in the maxim of respect for leaders ratifies hero-worship as in Animal Farm, unless the led want to lure the leaders into becoming despots. Rather than hero-worship, the led should give leaders the benefits of constructive criticism, never failing to applaud their populist accomplishments.

In case of corrupt or failed political leadership in any country, the led must not respond with revolution, nay, rebellion as the beasts of England did in Manor Farm when they lost confidence in Jones' government. This imperative is valid, because as subsequently seen in Animal Farm under the leadership of Napoleon and as supported by real political leadership experience across the globe revolution is no solution for dissatisfactory leadership. In Nigeria, for instance, no military regime has ever been adjudged better under any parameter than the one before it. Following Odumegwu-Ojukwu (1989), we recommend dialogue as the way forward in the face of leadership quagmire in any polity. To ensure effectiveness, the delegates of the led must be God-fearing people who are potential trust-worthy servant-leaders themselves, sufficiently vocal to impinge the voice of reason on the mind of the leaders. The dialogue should, of course, be aimed at achieving attitudinal transformation and ideological regeneration in the leaders in tandem with Orwell and Achebe's panacea for leadership failure as captured by Onyemelukwe (ibid.). Should dialogue fail, God forbid, change of leadership as the option of last resort becomes inevitable, but it must be effected through the ballot paper.

The led much like their leaders in any polity must be educated, especially in the formal sense. Moreover, they must continually seek enlightenment on both recurrent and non-recurrent national issues to avoid easy manipulation by the leaders as seen in Animal Farm. Again, to help ensure effective political leadership, the led should and must insist on a constitutional platform for securing periodic account of stewardship from their leaders. On the basis of this account, they should proceed to rewarding their effective leaders with second or even third terms and penalising dissatisfactory leaders with immediate recall or impeachment as may be applicable.

\section{Conclusion}

With analytical focus on Napoleon's dictatorship in Animal Farm, this study has evolved some political leadership imperatives. Foremost among the cardinal imperatives evolved in the study is that democracy is the only acceptable political leadership ideology. This notion is established in the study relying on Orwell's implicit but exclusive advocacy for it in Animal Farm as in Nineteen Eighty-four which is strongly underpinned by Achebe $(1958,1966,1987)$ and Onyemelukwe's $(2006,2011)$ same position. The trio of Orwell, Achebe and Onyemelukwe grant exclusive ratification to democracy which must be participatory and unbridled, because they see nothing good about totalitarianism and other right-wing political leadership ideologies such as fascism, maxism, stalinism and constitutional monarchy. In pragmatic terms, this foremost imperative translates to exemplary leadership which courageously serves to constantly reassure the led that they are neither enslaved to the leaders nor misled by them. 
In Napoleon's Animal Farm, Orwell apparently advocates socialism as the socio-economic ideology that should anchor democracy. We, however, propose capitalism as the right socio-economic ideological anchor for democracy, relying on insights from human experience which favour it, especially as it pertains to Africa. The capitalist economy proposed hereby must go with communalism to give it a human face. For avoidance of doubt, communalism refers to sharing material resources with the less privileged for the purpose of adding value to their life. Capitalism is preferred to socialism, because it enhances inclusive socio-economic growth quite unlike socialism and even communism which was practised by the defunct Soviet Union. Inclusive socio-economic growth carries the populace along such that standard of living improves tremendously among the citizenry as opposed to non-inclusive growth which wields geometric gross domestic product with zero bearing on standard of living. Nothing in the foregoing self-evident truths nullifies the wisdom of state management of public utilities such as electricity, water resources, telecommunication, aviation and rail transport cum security and law enforcement, all within the ambits of the constitution and legitimate edicts and penal codes.

Next to the imperative above is that political leadership must be altruistic and strategic to be effective. Going by this imperative which concurrently stems from the theoretical premise for the study, political leaders who must be God-fearing must assume the status of servant-leaders fully conscious of the maxim that political leadership is synonymous with sacrificial service to God and humanity, humanity as first represented by the citizens of their respective polities, because charity begins at home.

Finally, on our cardinal political leadership imperatives is that political leadership must be visionary and firm. The pragmatic import of this imperative is that political leaders should and must be formally educated, because formal education enhances cognitive ability which substantially bestows vision. Another pragmatic import of the imperative is that political leaders, especially at the gubernatorial or presidential level should not, even for a split second, hesitate to interdict or show the way out to erring subordinates without looking at their faces, those guilty of corruption and other gross misconducts, particularly. That is what it means to be firm or decisive as leaders. For instance, nothing stops Nigeria's Mr. President from sacking the country's current minister of petroleum resources for lavishing N10bn. on private jet chartering just for two years. The minister deserves the recommended termination of appointment, having proven herself guilty of corrupt practices by her unwarranted judicial attempt to scuttle public scrutiny on the matter under the auspices of the House of Representatives. See p.14 of The Punch of Wednesday, April 30, 2014. Let it here be cautioned that decision-making and implementation as a leadership function in political governance should and must not favour immoralities and/or illegalities as reflected in Kenya's 2014 polygamy law, no thanks to the country's current president. The immoral law permits a man to marry another wife without the permission of his previous wife or wives as may be the case.

To sustain effective political leadership, the led in every nation are enjoined in the study to ensure appreciative enlightened followership. Enlightened followership is such that monitors leadership by regularly demanding account of stewardship from the leaders. To live up to this ideal the led, as much as the leaders in a polity, must prioritise high-quality formal education to avoid hero-worshipping their leaders, else they become disguised despots. The foregoing role of the led is a necessary component of participatory (populist) democracy averred in this study to ensure that political power continually originates and devolves from the people. Hence the people are strongly urged never to elect as their leaders those who like Napoleon are eager for leadership, because such people seek power just for the glamour of it, and so, are potential disguised dictators.

\section{References}

Achebe, C. A. (1958). Things Fall Apart. Ibadan, Nigeria: Heinemann.

Achebe, C. A. (1966). A Man of the People. Ibadan, Nigeria: Heinemann.

Achebe, C. A. (1984). The Trouble with Nigeria. Enugu, Nigeria: Fourth Dimension Publishers.

Achebe, C. A. (1987). Anthills of the Savannah. Ibadan, Nigeria: Heinemann.

Achebe, C. A. (2012). There Was A Country...United States of America: Penguin Books (Allen Lane).

Adekambi, D. (2014). Harvest of Deaths and Economic Paralysis. Nigerian Tribune, Friday, 28 February, 2014. p. 25.

Akpenyi, M. E., \& Onyemelukwe, N. H. (2012). Linguistic Proficiency and National Development in Anglophone Africa. Journal of Arts and Education, 2(2).

Appadorai, A. (1975). The Substance of Politics. Calcutta: Oxford University Press.

Brander, L. (1960). In-text Introductory Notes on Animal Farm. Great Britain: Longman. 
Eagleton, T. (1991). Ideology: An Introduction, London New York: Verso.

Ewedemi, A. E. S. (2011). Strategic Management and Corporate Growth of Commercial Banks. A B.A. Project: Distance Learning Institute, University of Lagos, Nigeria.

FGN. (2011). Failed States Index.

Isola, A. (2008). Development in a Cultural Void? Journal of Language for Cultural and Technological Development (JOLCATED), 1(2), 1-18.

Iwara, A. U. (2008). The Linguistic Situation in Nigeria and its Implications for Sustainable Development. An Inaugural Lecture Delivered at The University of Ibadan, October, 2008.

Maxwell, C. (2008). Leadership Postulations as cited by Akpenyi, M. E. and Onyemelukwe, N. H. (2012). Linguistic Proficiency and National Development in Anglophone Africa, in Journal of Arts and Education, 2(2).

Maxwell, J. C. (2014). Quotes on Leadership in 2014 annual executive diary of Starco Insurance Plc.

Odumegwu-Ojukwu, E. (1989) Because I am Involved. Ibadan, Nigeria: Spectrum Books Ltd.

Ohiwerei, F. (2008). Preparing the Next Generation of Leaders: The Role of the Ivory Tower. $4^{\text {th }}$ Annual Lecture, University of Lagos School of Postgraduate Studies.

Onyemelukwe, N. H. (2006). A Stylistic Analysis of George Orwell's Nineteen Eighty-four. An M.A. Project, Department of English, Faculty of Arts, University of Ibadan, Nigeria.

Onyemelukwe, N. H. (2011). A Critical Discourse Analysis of Ideology and Meaning in Selected Novels of Chinua Achebe. An M. Phil. Degree Project, Department of English, University of Ibadan, Nigeria.

Onyemelukwe, N. H., \& Oriaku, R. O. (2011). Achebe's Things Fall Apart as a Compendium of Africanness. An International Conference Paper, University of Lagos.

Orwell, G. (1944). Animal Farm. London: Longman Group Ltd.

Orwell, G. (1948). Nineteen Eighty-four. New York: Penguin Books.

\section{Copyrights}

Copyright for this article is retained by the author(s), with first publication rights granted to the journal.

This is an open-access article distributed under the terms and conditions of the Creative Commons Attribution license (http://creativecommons.org/licenses/by/3.0/). 